University of Nebraska - Lincoln

DigitalCommons@University of Nebraska - Lincoln

1734

\title{
A Divine and Supernatural Light, Immediately imparted to the Soul by the Spirit of God, Shown to be both a Scriptural, and Rational Doctrine
}

Jonathan Edwards

Northampton (Congregational) Church

Reiner Smolinski

Georgia State University, rsmolinski@gsu.edu

Follow this and additional works at: https://digitalcommons.unl.edu/etas

Part of the American Literature Commons, American Popular Culture Commons, and the Religious Thought, Theology and Philosophy of Religion Commons

Edwards, Jonathan and Smolinski, Reiner, "A Divine and Supernatural Light, Immediately imparted to the Soul by the Spirit of God, Shown to be both a Scriptural, and Rational Doctrine" (1734). Electronic Texts in American Studies. 57.

https://digitalcommons.unl.edu/etas/57

This Article is brought to you for free and open access by the Libraries at University of Nebraska-Lincoln at DigitalCommons@University of Nebraska - Lincoln. It has been accepted for inclusion in Electronic Texts in American Studies by an authorized administrator of DigitalCommons@University of Nebraska - Lincoln. 


\section{Jonathan Edwards}

A Divine and Supernatural Light ( 1734$)$

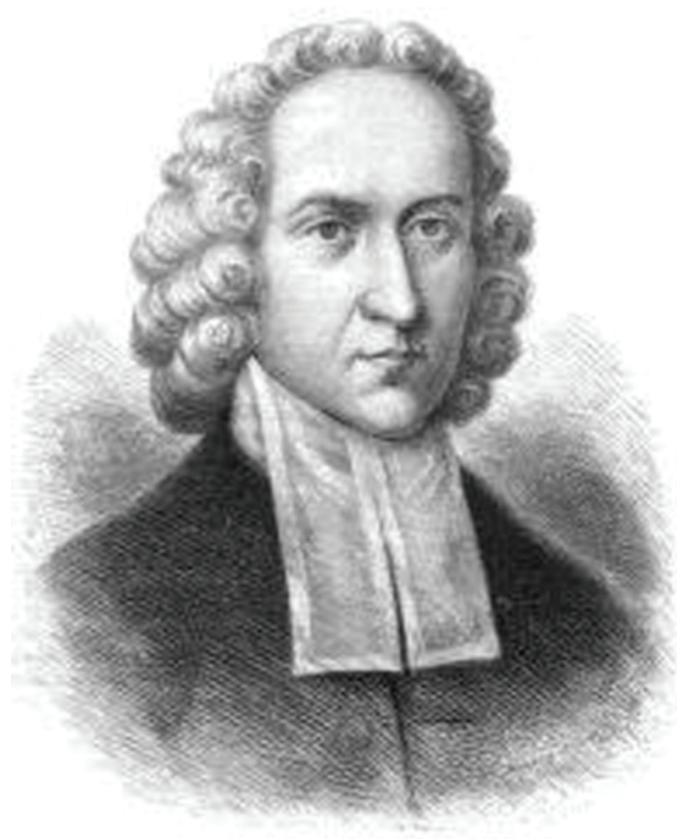

with an Afterword by Reiner Smolinski 


\section{A \\ Divine and Supernatural

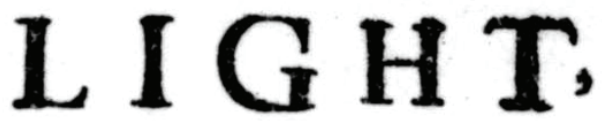

Immediately imparted to the Soul by tho

\section{SPIRIT of GOD,}

Shown to be both a

Scriptural, and Rational DOCTRINE

\section{In a SERMON}

Preach'd at Nortbamptoin,

And Publifhed at the Defire of fome of the Heaters.

Byfonathan Edwards, A. M.

Patot of the Church there.

Job 2 S. 20.-Whence then cometb exifdon? and wibere is the piace of windroffanding ?

Prov. 2. 6. Thbe LORD gicetb coifdom.

Ifa. 42. is. Look ye blind tisat ye may fee.

2 Pet. 1. 19. Cintil tbe day doews and tbe day-fsaty anif; in your beasts.

$B O S T O N$ :

Printed by S. Xntetand and T. Gaza!: $\mathrm{Mj}_{\mathrm{j} \mathrm{DCC}_{\mathrm{g}} \mathrm{XXIV}}$ 


\section{A \\ Divine and Supernatural L I G H T,}

Immediately imparted to the Soul by the

\section{SPIRIT of GOD,}

Shown to be both a

Scriptural, and Rational DoctRINE;

\section{In a $\mathrm{SERMON}$}

Preach'd at Northampton,

And Publifhed at the Desire of fome of the Hearers.

\section{By Fonathan Edwards, A. M.}

Paftor of the Church there.

Job. 28. 20. Whence then cometh wifdom? and where is the place of underfttanding?

Prov. 2. 6. The LORD giveth wifdom.

Isa. 42. I8. Look ye blind that ye may fee.

2 Pet. I. I9. - Until the day dawn and the day-ftar arife in your bearts.

$B O S T O N:$

Printed by S. Kneeland and T. Green.

$$
\text { M,DCC,XXXIV }
$$





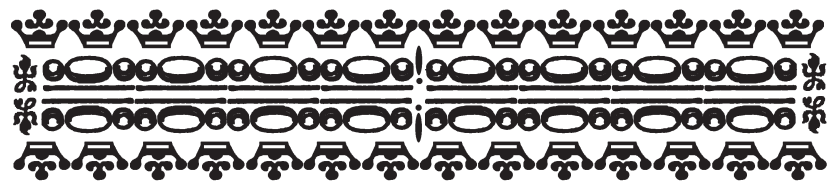

\section{The PREFACE.}

ary sensible that my consenting that the fol205350 lowing Discourse of mine should be pubI lished, needs Excuse; but yet don't think cos as it worth the while for me, here, to excuse my self, by declaring how backmard I was to it, and bow much I mas urged, and that I was prevail'd with to do it, more to gratify others, and from an Aim at promoting the Interest of Religion, and the Good of Souls, than by any thought I had of any Honour that I should get by it: for such things, I apprebend, ordinarily make less Impression upon the Readers, to alter their thought of the Author, and his Design, than the Authors generally think for. They at whose desire, and upon whose Account chiefly, this Sermon is printed, are already acquainted with the Circumstances of the Matter; and if any others should happen to see it, and should think it worth their while to read it, I shall only desire of them, that they would put as favourable a Construction upon my berein appearing in Print, as they can; and that they would read the following Discourse with Candour, and without Prejudice against it, either from an Idea of the Author's Formardness and Ostentation, or the Unfashionableness of the Subject. As to you, that are the People of the Flock, of mbich CHRIST hath called me to the Oversight, I have no Rea- 


\section{T H E P R E F A C E}

son to be jealous that you mill have any Prejudice against this Discourse, upon either of those mention'd Accounts, to stand in the way of your duly weighing, and considering, and suitably entertaining the things treated of in it. I have Reason to bless GOD, that here is a more happy Union between us, than that you should be prejudiced against any thing of mine, because 'tis mine; And bowever the subject is out of Mode in the World, 'tis doubtless your peculiar Happiness, that you bave been so thoroughly instructed in such like Doctrine, even from your Beginning: and I rejoice in it, that Providence, in this Day of Corruption and Confusion, has cast my Lot where such Doctrines, that I look upon so much the Life and Glory of the Gospel, are not only own'd, but where there are so many, in whom the Truth of them is so apparently manifest, in their Experience, that any one who has had the Opportunity of Acquaintance with them in such mattes, that I have had, must be very unreasonable to doubt of it. It is pleasant to me to read discourses on such Subjects, and to see such Doctrines mell treated of in Books, but much more pleasant, to see them clearly exemplified. If what is here offered to you, shall be a means further to establish you in such Truths, and to make those among you, that yet remain in spiritual Darkness and Blindness, sensible of their Misery, and stir them up earnestly to seek after this spiritual and divine Illumination; and shall be for the Comfort and Edification of those that have Experienced it, I shall have great Reason to rejoice, and be thankful: and $I$ desire your earnest and continual Prayers for me, that I may be the Instrument of much such Good to you, and Glory to GOD therein.

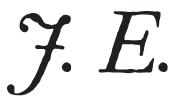




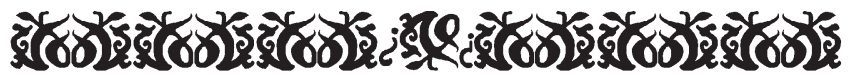

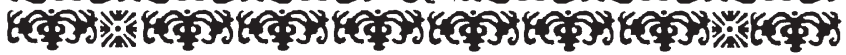

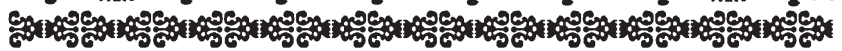

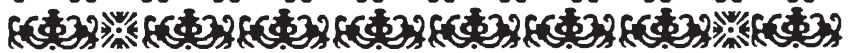
(2)

THE

$$
\text { Reality of Spiritual Light. }
$$

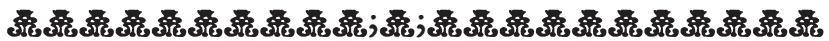

Matтhew XVI. I7.

And FESUS answered and said unto him, blessed art thou Simon Barjona; for Flesh and Blood hath not revealed it unto thee, but my Father which is in Heaven.

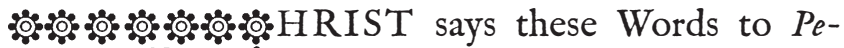
: i⿱⺈ 20 20

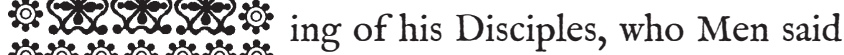
มำ he was; not that he needed to be informed, but only to introduce and give Occasion to what follows. They answer, that some said he was Fobn the Baptist, and some Elias, and others feremias or one of the Prophets. When they had thus given an Account, who others said he was, CHRIST asks them, who they said he was. Simon Peter, whom 
we find always zealous and forward, was the first to answer; he readily replied to the Question, Thou art CHRIST the Son of the living GOD.

UPON this Occasion CHRIST says as he does to him and of him in the Text : In which we may observe,

I. THAT Peter is pronounced blessed on this Account. Blessed art thou - "Thou art an happy " man, that thou art not ignorant of this, that I am "CHRIST the Son of the living GOD. Thou art dis" tinguishingly happy. Others are blinded, and have " dark and deluded Apprehensions, as you have now " given an Account, some thinking that I am Elias, " and some that I am feremias, and some one thing, " and some another; but none of them thinking right, " all of them misled. Happy art thou, that art so dis" tinguished as to know the Truth in this Matter.

2. THE Evidence of this his Happiness declared; viz. That GOD and he only had revealed it to him. This is an Evidence of his being blessed.

First, AS it shows how peculiarly favoured he was of GOD, above others. q. d. "How highly " favoured art thou, that others that are wise and " great Men, the Scribes, Pharisees, and Rulers, and " the Nation in general, are left in Darkness, to fol" low their own misguided Apprehensions, and that " thou should'st be singled out, as it were by Name, " that my heavenly Father should thus set his Love " on thee Simon Bar-jona. This argues thee blessed, " that thou should'st thus be the Object of GOD's "distinguishing Love. 
Secondly, IT evidences his Blessedness also, as it intimates that this Knowlege is above any that Flesh and Blood can reveal. "This is such Knowlege as my "Father which is in Heaven only "can give: It is too "high and excellent to be communicated by such Means " as other Knowlege is. Thou art blessed, that thou " knowest that which GOD alone can teach thee.

THE Original of this Knowlege is here declared; both negatively and positively. Positively, as GOD is here declared the Author of it. Negatively, as 'tis declared that Flesh and Blood had not revealed it. GOD is the Author of all Knowlege and Understanding whatsoever: $\mathrm{He}$ is the Author of the Knowlege, that is obtained by human Learning: He is the Author of all moral Prudence, and of the Knowlege and Skill that Men have in their secular Business. Thus it is said of all in Israel that were mise-hearted, and skill'd in Embroidering, that GOD had fill'd them with the spirit of Wisdom. Exod. 28. 3.

GOD is the Author of such Knowlege; but yet not so but that Flesh and Blood reveals it. Mortal Men are capable of imparting the Knowlege of human Arts and Sciences, and Skill in temporal Affairs. GOD is the Author of such Knowlege by those Means: Flesh and Blood is made use of by GOD as the mediate or second Cause of it; He conveys it by the Power and Influence of natural Means. But this spiritual Knowlege, spoken of in the Text, is what GOD is the Author of, and none else: He reveals it and Flesh and Blood reveals it not. He imparts this Knowlege immediately, 
not making use of any intermediate Causes, as he does in other Knowlege.

WHAT had passed in the preceeding Discourse, naturally occasioned CHRIST to observe this; because the Disciples had been telling, how others did not know him, but were generally mistaken about him, and divided and confounded in their Opinions of him: but Peter had declared his assured Faith that he was the Son of GOD. Now it was natural to observe, how it was not Flesh and Blood, that had revealed it to him, but GOD; for if this knowlege were dependent on natural Causes or Means, how came it to pass that they, a Company of poor Fishermen, illiterate Men, and Persons of low Education, attain'd to the knowlege of the Truth; while the Scribes and Pharisees, Men of vastly higher advantages, and greater knowlege and sagacity in other matters, remain'd in Ignorance? This could be owing only to the gracious distinguishing Influence and Revelation of the SPIRIT of GOD. Hence, what I would make the Subject of my present Discourse from these Words, is this

\section{O C T R I N E, viz.}

That there is such a thing as A SPIRITUAL and DIVINE LIGHT, immediately imparted to the Soul by GOD, of a different Nature from any that is obtain'd by natural Means. 
IN what I say on this Subject at this Time, I would

I. SHOW what this divine Light is.

II. HOW it is given Immediately by GOD, and not obtain'd by natural Means.

III. SHOW the Truth of the Doctrine.

AND then conclude with a brief Improvement.

I. I would show what this spiritual and divine Light is. And in order to it would shew,

First, IN a few things what it is not. And here,

I. THOSE Convictions that natural Men may have of their Sin and Misery is not this spiritual and divine Light. Men in a natural Condition may have Convictions of the Guilt that lies upon them, and of the anger of GOD, and their Danger of divine Vengeance. Such Convictions are from Light or Sensibleness of Truth: that some Sinners have a greater Conviction of their Guilt and Misery than others, is because some have more Light, or more of an Apprehension of 'Truth, than others. And this Light and Conviction may be from the Spirit of GOD; the SPIRIT convinces Men of Sin: but yet nature is much more concern'd in it than in the Communication of that spiritual and divine Light, that is spoken of in the Doctrine; 'tis from the Spirit of GOD only as assisting natural Principles, and not as infusing any new Princi- 
ples. Common Grace differs from special, in that it influences only by assisting of Nature; and not by imparting Grace, or bestowing any thing above Nature. The Light that is obtain'd, is wholly natural, or of no superiour Kind to what meer Nature attains to; tho' more of that kind be obtained, than would be obtained if Men were left wholly to themselves, Or in other Words, Common Grace only assists the Faculties of the Soul to do that more fully, which they do by Nature; as natural Conscience, or Reason, will by meer Nature make a Man sensible of Guilt, and will accuse and condemn him when he has done amiss. Conscience is a Principle natural to Men; and the Work that it doth naturally, or of it self, is to give an Apprehension, of right and wrong; and to suggest to the Mind the Relation that there is between right and wrong, and a Retribution. The Spirit of GOD, in those Convictions which unregenerate Men sometimes have, assists Conscience to do this Work in a further Degree, than it would do if they were left to themselves: He helps it against those Things that tend to stupify it, and obstruct its Exercise. But in the renewing and sanctifying work of the HOLY GHOST, those things are wrought in the Soul that are above Nature; and of which there is nothing of the like kind in the Soul by Nature; and they are caused to exist in the Soul habitually, \& according to such a stated Constitution or Law, that lays such a Foundation for Exercises in a continued Course, as is called a Principle of nature. Not only are remaining Principles assisted to do their work more freely and fully, but those Principles are restored that were utterly destroyed by the Fall; and the mind 
thence-forward habitually exerts those acts that the Dominion of Sin had made it as wholly destitute of, as a dead Body is of vital Acts.

THE Spirit of GOD acts in a very different manner in the one Case, from what he doth in the other. He may indeed act upon the Mind of a natural Man; but he acts in the Mind of a Saint as an indwelling vital Principle. He acts upon the Mind of an unregenerate Person as an extrinsick occasional Agent; for in acting upon them he doth not unite himself to them; for notwithstanding all his Influences that they may be the Subjects of, they are still sensual having not the Spirit. Fude 19. But he unites himself with the Mind of a Saint, takes him for his Temple, actuates and influences him as a new, supernatural Principle of Life and Action. There is this Difference; that the Spirit of GOD in acting in the Soul of a Godly Man, exerts and communicates himself there in his own proper Nature. Holiness is the proper Nature of the Spirit of GOD. The HOLY SPIRIT operates in the Minds of the Godly, by uniting himself to them, and living in them, and exerting his own Nature in the Exercise of their Faculties. The Spirit of GOD may act upon a Creature, and yet not, in acting communicate himself. The Spirit of GOD may act upon inanimate Creatures; as the Spirit moved upon the Face of the Waters, in the Beginning of the Creation: So the Spirit of GOD may act upon the minds of Men, many ways, and communicate himself no more than when he acts upon an inanimate Creature. For Instance. He may excite Thoughts in them, may assist their natural Rea- 
son and Understanding, or may assist other natural Principles, and this without any Union with the Soul, but may act, as it were, as upon an external Object. But as he acts in his holy Influences, and spiritual Operations, he acts in a way of peculiar Communication of himself; so that the Subject is thence denominated Spiritual.

2. THIS spiritual and divine Light don't consist in any Impression made upon the Imagination. 'Tis no Impression upon the Mind, as tho' one saw any thing with the bodily Eyes: 'Tis no Imagination or Idea of an outward Light or Glory, or any Beauty of Form or Countenance, or a visible Lustre or Brightness of any Object. The Imagination may be strongly impress'd with such things; but this is not spiritual Light. Indeed when the Mind has a lively Discovery of spiritual things, and is greatly affected by the Power of divine Light, it may, and probably very commonly doth, much affect the Imagination: So that Impressions of an outward Beauty or Brightness, may accompany those spiritual Discoveries. But spiritual Light is not that Impression upon the Imagination, but an exceeding different thing from it. Natural Men may have lively Impressions on their Imaginations; and we cant determine but that the Devil, who transforms himself into an Angel of Light, may cause Imaginations of an outward Beauty, or visible Glory, and of Sounds and Speeches, and other such Things; but these are Things of a vastly inferiour Nature to Spiritual Light. 
3. THIS spiritual Light is not the suggesting of any new Truths, or Propositions not contain'd in the Word of GOD. This suggesting of new Truths or Doctrines to the Mind, independent of any antecedent Revelation of those Propositions, either in Word or Writing, is Inspiration; such as the Prophets and Apostles had, and such as some Enthusiasts pretend to. But this spiritual Light that I am speaking of, is quite a different thing from Inspiration: It reveals no new Doctrine, it suggests no new Proposition to the Mind, it teaches no new thing of GOD, or CHRIST, or another World, not taught in the Bible; but only gives a due Apprehension of those things that are taught in the word of GOD.

4. 'TIS not every affecting Viem that Men have of the Things of Religion, that is this spiritual and divine Light. Men by meer Principles of Nature are capable of being affected with Things that have a special Relation to Religion, as well as other Things. A Person by meer Nature, for Instance, may be liable to be affected with the Story of JESUS CHRIST, and the sufferings he underwent, as well as by any other tragical Story: He may be the more affected with it from the Interest he conceives Mankind to have in it: Yea he may be affected with it without believing it; as well as a Man may be affected with what he reads in a Romance, or see's acted in a Stage Play. He may be affected with a lively and eloquent description of many pleasant things that attend the state of the Blessed in Heaven; as well as his Imagination be entertain'd by a romantick description of the pleasantness of Fairy Land, or the like. And that common belief of the truth of the 
things of Religion, that Persons may have from Education, or otherwise, may help forward their affection. We read in Scripture of many that were greatly affected with things of a religious nature, who yet are there represented as wholly graceless, and many of them very ill Men. A Person therefore may have affecting viems of the things of Religion, and yet be very destitute of spiritual Light. Flesh and Blood may be the Author of this: One Man may give another an affecting view of divine things with but common assistance; but GOD alone can give a spiritual Discovery of them.

BUT I proceed to show,

Secondly, Positively, WHAT this spiritual and divine Light is.

AND it may be thus described, $A$ true sense of the divine Excellency of the things revealed in the Word of GOD, and a conviction of the truth and reality of them, thence arising.

THIS spiritual Light primarily consists in the former of these, viz. a real sense and apprehension of the divine Excellency of things revealed in the Word of GOD. A spiritual and saving Conviction of the truth and reality of these things, arises from such a sight of their divine Excellency and Glory; so that this Conviction of their truth is an effect and natural consequence of this sight of their divine Glory. There is therefore in this spiritual Light,

I. A true sense of the divine and superlative excellency of the things of Religion; a real sense of the excellency of GOD, and JESUS CHRIST, and of the work 
of Redemption, and the ways and works of GOD revealed in the Gospel. There is a divine and superlative Glory in these things; and Excellency that is of a vastly higher Kind, and more sublime Nature, than in other thing; a Glory greatly distinguishing them from all that is earthly and temporal. He that is spiritually enlightened truly apprehends and sees it, or has a sense of it. He don't meerly rationally believe that GOD is Glorious, but he has a sense of the Gloriousness of GOD in his Heart. There is not only a rational belief that GOD is holy, and that Holiness is a good thing; but there is a sense of the Loveliness of GOD's Holiness. There is not only a speculatively judging that GOD is gracious, but a sense how amiable GOD is upon that Account; or a sense of the Beauty of this divine Attribute.

THERE is a twofold Understanding of Knowledge of Good, that GOD has made the Mind of Man capable of. The First, that which is meerly speculative or notional: As when a Person only speculatively judges, that any thing is, which by the Agreement of Mankind, is called Good or Excellent, viz. that which is most to general Advantage, and between which and a Reward there is a suitableness; and the like. And the other is that which consists in the sense of the Heart: As when there is a sense of the Beauty, Amiableness, or Sweetness of a thing; so that the Heart is sensible of Pleasure and Delight in the presence of the Idea of it. In the former is exercised meerly the speculative Faculty, or the Understanding strictly so called, or as spoken of in Distinction from 
the Will or Disposition of the Soul. In the latter the Will, or Inclination, or Heart, are mainly concern'd.

THUS there is a Difference between having an Opinion that GOD is holy and gracious, and having a sense of the Loveliness and Beauty of that Holiness and Grace. There is a Difference between having a rational Fudgment that Honey is sweet, and having a sense of its sweetness. A Man may have the Former, that knows not how Honey tasts; but a Man can't have the Latter, unless he has an Idea of the tast of Honey in his Mind. So there is a difference between believing that a Person is Beautiful, and having a sense of his Beauty. The Former may be obtain'd by hear-say, but the Latter only by seeing the Countenance. There is a wide difference between meer speculative, rational fudging any thing to be excellent, and having a sense of its Sweetness, and Beauty. The Former rests only in the Head, Speculation only is concern'd in it; but the Heart is concern'd in the Latter. When the Heart is sensible of the Beauty and Amiableness of a Thing, it necessarily feels Pleasure in the Apprehension. It is implied in a Persons being heartily sensible of the Loveliness of a thing, that the Idea of it is sweet and pleasant to his Soul; which is a far different thing from having a rational Opinion that it is excellent.

2. THERE arises from this sense of divine Excellency of 'Things contain'd in the Word of GOD, a Conviction of the Truth and Reality of them: and that either indirectly, or directly. 
First, Indirectly, and that two ways.

I. AS the Prejudices that are in the Heart, against the truth of divine things, are hereby removed; so that the Mind becomes susceptive of the due Force of rational Arguments for their Truth. The Mind of Man is naturally full of Prejudice against the Truth of divine Things: It is full of Enmity against the Doctrines of the Gospel; which is a disadvantage to those Arguments that prove their Truth, and causes them to lose their Force upon the Mind. But when a Person has discovered to him the divine excellency of Christian Doctrines, this destroys the Enmity, removes those Prejudices, and sanctifys the Reason, and causes it to lie open to the Force of Arguments for their Truth.

HENCE was the different Effect that CHRIST's Miracles had to convince the Disciples, from what they had to convince the Scribes and Pharisees. Not that they had a stronger Reason, or had their Reason more improved; but their Reason was sanctified, and those blinding Prejudices, that the Scribes and Pharisees were under, were removed by the sense they had of the Excellency of CHRIST, and his Doctrine.

2. IT not only removes the Hindrances of Reason, but positively helps Reason. It makes even the speculative Notions the more lively. It engages the attention of the Mind, with the more Fixedness and Intenseness to that Kind of Objects; which causes it to have a clearer View of them, and enables it more clearly to see their mutual Relations, and occasions 
it to take more Notice of them. The Ideas themselves that otherwise are dim, and obscure, are by this Means impress'd with the greater Strength, and have a Light cast upon them; so that the Mind can better judge of them. As he that beholds the Objects on the Face of the Earth, when the Light of the Sun is cast upon them, is under greater Advantage to discern them in their true Forms, and mutual Relations, than he that sees them in a dim Star-light or Twilight.

The Mind having a sensibleness of the Excellency of divine Objects, dwells upon them with Delight; and the Powers of the Soul are more awaken'd, and enliven'd to employ themselves in the Contemplation of them, and exert themselves more fully and much more to Purpose. The Beauty and Sweetness of the Objects draws on the Faculties, and draws forth their Exercises: So that Reason it self is under far greater Advantages for its proper and free Exercises, and to attain its proper End, free of Darkness and Delusion. But,

Secondly, A true sense of the divine Excellency of the Things of GOD's Word doth more directly and immediately convince of the Truth of them; And that because the Excellency of these Things is so superlative. There is a Beauty in them that is so divine and Godlike, that is greatly and evidently distinguishing of them from things meerly human, or that Men are the Inventors and Authors of; a Glory that is so high and great, that when clearly seen, commands Assent to their Divinity, and Reality. When there is an actual and lively Discovery of this Beauty and Excel- 
lency, it won't allow of any such Thought as that it is an human Work, or the Fruit of Mens Invention. This Evidence, that they, that are spiritually enlightened, have of the Truth of the things of Religion, is a Kind of intuitive and immediate Evidence. They believe the Doctrines of GOD's Word to be divine, because they see Divinity in them, i.e. They see a divine, and transcendent, and most evidently distinguishing Glory in them; such a Glory as, if clearly seen, don't leave Room to doubt of their being a GOD, and not of Men.

SUCH a Conviction of the Truth of Religion as this, arising, these Ways, from a sense of the divine Excellency of them, is that true spiritual Conviction, that there is in saving Faith. And this Original of it, is that by which it is most essentially distinguished from that common assent, which unregenerate Men are capable of.

II. I Proceed now to the second Thing proposed, viz. To show how this Light is Immediately given by GOD, and not obtain'd by natural Means. And here,

I. 'TIS not intended that the natural Faculties are not made $U_{\text {se }}$ of in it. The natural Faculties are the Subject of this Light: And they are the Subject in such a Manner, that they are not meerly passive, but active in it; the Acts and Exercises of Man's Understanding are concern'd and made use of in it. GOD in letting in this Light into the Soul, deals with Man according to his Nature, or as a rational Creature; and makes Use of his human Faculties. But yet this Light is 
not the less immediately from GOD for that; tho' the

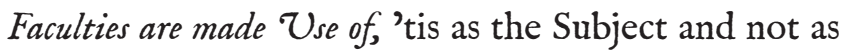
the Cause; and that acting of the Faculties in it, is not the Cause, but is either implied in the Thing it self, (in the Light that is imparted) or is the Consequence of it. As the Use that we make of our Eyes in beholding various Objects, when the Sun arises, is not the Cause of the Light that discovers those Objects to us.

2. 'TIS not intended that outward Means have no Concern in this Affair. As I have observed already, 'tis not in this Affair, as it is in Inspiration, where new Truths are suggested: for here is by this Light only given a due Apprehension of the same Truths that are revealed in the Word of GOD; and therefore it is not given without the Word. The Gospel is made Use of in this Affair: This Light is the Light of the Glorious Gospel of CHRIST 2. Cor. 4. 4. The Gospel is as a Glass, by which this Light is conveyed to us. I Cor. I3. I2. Now we see through a Glass-. But,

3. WHEN it is said that this Light is given immediately by GOD, and not obtained by natural Means, hereby is intended, that 'tis given by GOD without making Use of any Means that operate by their own Power, or a natural Force. GOD makes Use of Means; but 'tis not as mediate Causes to produce this Effect. There are not truly any second Causes of it; but it is produced by GOD immediately. The Word of GOD is no proper Cause of this Effect: It don't operate by any natural Force in it. The Word of GOD is only made Use of to convey to the Mind the Sub- 
ject matter of this saving Instruction: And this indeed it doth convey to us by natural Force or Influence. It conveys to our Minds these and those Doctrines; it is the Cause of the Notion of them in our Heads, but not of the sense of the divine Excellency of them in our Hearts. Indeed a Person can't have spiritual Light without the Word. But that don't argue, that the Word properly causes that Light. The Mind can't see the Excellency of any Doctrine, unless that Doctrine be first in the Mind; but the seeing the Excellency of the Doctrine may be immediately from the Spirit of GOD; tho' the conveying of the Doctrine or Proposition it self may be by the Word. So that the Notions that are the Subject matter of this Light, are conveyed to the Mind by the Word of GOD; but that due sense of the Heart, wherein this Light formally consists, is immediately by the Spirit of GOD. As for Instance, that Notion that there is a CHRIST, and that CHRIST is holy and gracious, is conveyed to the Mind by the Word of GOD: But the sense of the Excellency of CHRIST by reason of that Holiness and Grace, is nevertheless immediately the Work of the HOLY SPIRIT. I come now,

III. TO show the Truth of the Doctrine; that is to show that there is such a Thing as that spiritual Light that has been described, thus immediately let into the Mind by GOD. And here I would shew briefly, that this Doctrine is both scriptural, and rational.

First, 'TIS SCRIPTURAL. My Text is not only full to the Purpose, but 'tis a Doctrine that the 
Scripture abounds in. We are there abundantly taught, that the Saints differ from the Ungodly in this, that they have the Knowlege of GOD, and a sight of GOD, and of JESUS CHRIST. I shall mention but few Texts of many; I John 3. 6. Whosoever sinneth hath not seen him, nor known him. 3 John Ir. He that doth Good, is of GOD; but he that doth Evil, bath not seen GOD. John I4. I9. The world seeth me no more; but ye see me. John I7. 3. And this is Eternal Life, that they might know thee, the only true GOD, and FESUS CHRIST whom thou hast sent. This Knowlege, or sight of GOD and CHRIST, can't be a meer speculative Knowlege; because it is spoken of as a seeing and knowing, wherein they differ from the Ungodly. And by these Scriptures it must not only be a different Knowlege in Degree and circumstances, and different in its Effects; but it must be entirely different in Nature and Kind.

AND this Light and Knowlege is always spoken of as immediately given of GOD. Mat. Ir. 25, 26, 27. At that time fESUS answered and said, I thank thee $O$ Father Lord of Heaven and Earth, because thou bast hid these things from the wise and prudent, and hast revealed them unto Babes; even so Father, for so it seemed good in thy sight. All things are delivered unto me of my Father; and no Man knoweth the Son but the Father; neither knoweth any Man the Father, save the Son, and he to whomsoever the Son mill reveal him. Here this Effect is ascribed alone to the arbitrary Operation, and Gift of GOD, bestowing this Knowlege on whom he will, and distinguishing those with it, that have the least natural Ad- 
vantage or Means for Knowlege, even Babes, when it is denied to the Wise and Prudent. And the imparting the Knowlege of GOD is here appropriated to the Son of GOD, as his sole Prerogative. And again, 2 Cor. 4. 6. For GOD who commanded the Light to shine out of Darkness, hath shined in our Hearts, to give the Light of Knomlege of the Glory of GOD in the Face of $F E S U S$ CHRIST. This plainly shows, that there is such a thing as a discovery of the divine superlative Glory and Excellency of GOD and CHRIST; and that peculiar to the Saints: and also that 'tis as immediately from GOD, as Light from the Sun: and that 'tis the immediate Effect of his Power and Will; for 'tis compared to GOD's creating the Light by his powerful Word in the beginning of the Creation; and is said to be by the Spirit of the LORD, in the eighteenth verse of the preceeding Chapter. GOD is spoken of as giving the Knowlege of CHRIST in Conversion, as of what before was hidden and unseen in that Gal. I. I5, I6. But when it pleased GOD, who separated me from my Mothers Womb, and called me by his Grace, to reveal his Son in me —. The Scripture also speaks plainly of such a Knowlege of the Word of GOD, as has been described, as the immediate gift of GOD. Psal. II9. I8. Open thou mine Eyes, that I may behold mondrous things out of thy Law. What could the Psalmist mean, when he begged of GOD to open his Eyes? was he ever blind? might he not have Resort to the Law and see every Word and Sentence in it when he pleased? And what could he mean by those mondrous Things? was it the wonderful Stories of the Creation, 
and Deluge, and Israel's passing thro' the red Sea, and the like? were not his Eyes open to read these strange things when he would? Doubtless by mondrous Things in GOD's Law, he had Respect to those distinguishing and wonderful Excellencies, and marvellous Manifestations of the divine Perfections, and Glory, that there was in the Commands and Doctrines of the Word, and those Works and Counsels of GOD that were there revealed. So the Scripture speaks of a Knowlege of GOD's Dispensation, and Covenant of Mercy, and Way of Grace towards his People, as peculiar to the Saints, and given only by GOD, Psal. 25. 14. The Secret of the LORD is with them that fear him; and he will shew them his Covenant.

AND that a true and saving Belief of the Truth of Religion is that which arises from such a Discovery, is also what the Scripture teaches. As John 6. 40. And this is the will of him that sent me, that every one that SEETH the Son, and BELIEVETH on him, may have everlasting Life. Where it is plain that a true Faith is what arises from a spiritual sight of CHRIST. And John I 7. 6, 7, 8. I have manifested thy Name unto the Men which thou gavest me out of the World-. Now they have known that all things whatsoever thou hast given me, are of thee; for I have given unto them the words which thou gavest me, and they have received them, and known surely that I came out from thee, and they bave believed that thou didst send me. Where CHRIST's manifesting GOD's Name to the Disciples, or giving them the Knowlege of God, was that whereby they knew that CHRIST's 
Doctrine was of GOD, and that CHRIST himself was of him, proceeded from him, and was sent by him. Again John 12. 44, 45, 46. FES US cried and said, be that believeth on me, believeth not on me, but on bim that sent me; and he that seeth me seeth him that sent me: I am come a Light into the World, that whosoever Believeth on me should not abide in Darkness. There Believing in CHRIST and spiritually Seeing him, are spoken of as running parallel.

CHRIST condemns the Jews, that they did not know that he was the MESSIAH, and that his Doctrine was true, from an inward distinguishing Tast and Relish of what was divine, in Luke 12. 56, 57. He having there blamed the Jews, that though they could discern the Face of the Sky and of the Earth, and Signs of the Weather, that yet they could not discern those Times; or as 'tis expressed in Matthem, the Signs of those Times; He adds, yea and why even of your own selves, judge ye not what is right? i. e. without extrinsick Signs. "Why have ye not that sense of true "Excellency, whereby ye may distinguish that which " is holy and divine? Why have ye not that favour " of the things of GOD, by which you may see the " distinguishing Glory, and evident Divinity of me " and my Doctrine?

THE Apostle Peter mentions it as what gave them (the Apostles,) good and well grounded Assurance of the Truth of the Gospel, that they had seen the divine Glory of CHRIST. 2 Pet. I. I6. For we have not followed cunningly devised Fables, when we 
made known unto you, the Power and Coming of our Lord FESUS CHRIST, but were Eye-mitnesses of his Majesty. The Apostle has Respect to that visible Glory of CHRIST which they saw in his Transfiguration: That Glory was so divine having such an ineffable Appearance and semblance of divine Holiness, Majesty, and Grace, that it evidently denoted him to be a divine Person. But if a sight of CHRIST's outward Glory might give a rational Assurance of his Divinity, why may not an Apprehension of his spiritual Glory do so too. Doubtless CHRIST's spiritual Glory is in itself as distinguishing, and as plainly shewing his Divinity, as his outward Glory; and a great deal more: for his spiritual Glory is that wherein his Divinity consists; and the outward Glory of his Transfiguration shew'd him to be divine, only as it was a Remarkable Image or Representation of that spiritual Glory. Doubtless therefore he that has had a clear sight of the spiritual Glory of CHRIST, may say, I have not followed cunningly devised Fables, but have been an Eye-mitness of his Majesty, upon as good Grounds as the Apostle, when he had Respect to the outward Glory of Christ, that he had seen. But this brings me to what was proposed next viz. to show that,

Secondly, THIS Doctrine is RATIONAL.

I. 'TIS rational to suppose that there is really such an Excellency in divine things, that is so transcendent and exceedingly different from what is in other things, that if it were seen would most evidently distinguish them. We can't rationally doubt but that Things that are divine, that 
appertain to the supreme Being, are vastly different from Things that are human; that there is that Godlike, high, and glorious Excellency in them, that does most remarkably difference them from the things that are of Men; insomuch that if the difference were but seen, it would have a convincing, satisfying influence upon any one, that they are what they are, viz. divine. What Reason can be offered against it? Unless we would argue that GOD is not remarkably distinguished in Glory from Men.

IF CHRIST should now appear to any One, as he did on the Mount at his Transfiguration; or if he should appear to the World in the Glory that he now appears in in Heaven, as he will do at the Day of Judgment; without doubt, the Glory and Majesty that he would appear in, would be such as would satisfy every One, that he was a divine Person, and that Religion was true: And it would be a most reasonable, and well grounded Conviction too. And why may there not be that Stamp of Divinity, or divine Glory on the word of GOD, on the Scheme and Doctrine of the Gospel, that may be in like manner distinguishing and as rationally convincing, provided it be but seen? 'Tis rational to suppose, that when GOD speaks to the World, there should be something in his Word or Speech vastly different from Men's Word. Supposing that GOD never had spoken to the World, but we had Notice that He was about to do it; that he was about to Reveal himself from Heaven, and speak to us immediately himself, in divine Speeches or Discourses, as it were from 
his own Mouth; or that he should give us a Book of his own inditing; after what manner should we expect that he would speak? Would it not be rational to suppose, that his Speech would be exceeding different from Men's Speech, that he should speak like a GOD; that is, that there should be such an Excellency and sublimity in his Speech or Word, such a Stamp of Wisdom, Holiness, Majesty, and other divine Perfections, that the word of Men, yea of the wisest of Men, should appear mean and base in Comparison of it? Doubtless it would be thought rational to expect this, and unreasonable to think otherwise. When a wise Man speaks in the Exercise of his Wisdom, there is something in every thing he says, that is very distinguishable from the Talk of a little Child. So, without doubt, and much more, is the Speech of GOD, (if there be any such Thing as the Speech of GOD,) to be distinguished from that of the wisest of Men; agreable to Fer. 23. 28, 29. GOD having there been reproving the false Prophets that prophesied in his Name, and pretended that what they spake was his Word, when indeed it was their own Word, says, The Prophet that hath a Dream, let him tell a Dream; and he that hath my Word, let him speak my Word faithfully: WHAT IS THE CHAFF TO THE WHEAT ? Saith the LORD. Is not my Word like as a Fire, saith the LORD, and like a Hammer that breaketh the Rock in Pieces?

2. IF there be such a distinguishing Excellency in divine things; 'tis rational to suppose that there may be such a thing as seeing it. What should hinder but that it may be seen? 'Tis no Argument that there is no such Thing as such 
a distinguishing Excellency, or that, if there be, that it can't be seen, that some don't see it; tho' they may be discerning Men in temporal Matters. It is not rational to suppose, if there be any such Excellency in divine Things, that wicked Men should see it. 'Tis not rational to suppose, that those whose Minds are full of spiritual Pollution, and under the Power of filthy Lusts, should have any Relish or Sense of divine Beauty, or Excellency; or that their Minds should be susceptive of that Light that is in its own Nature so pure and heavenly. It need not seem at all strange, that Sin should so blind the Mind, seeing that Mens particular natural Tempers and Dispositions will so much blind them in secular Matters; as when Mens natural Temper is melancholy, jealous, fearful, proud, or the like.

3. 'TIS rational to suppose that this Knomlege should be given immediately by GOD, and not be obtain'd by natural means. Upon what account should it seem unreasonable, that there should be any immediate Communication between GOD and the Creature? 'Tis strange that Men should make any matter of difficulty of it. Why should not He that made all things, still have something immediately to do with the Things that he has made? Where lies the great difficulty, if we own the Being of a GOD, and that he created all things out of Nothing, of allowing some immediate Influence of GOD on the Creation still. And if it be reasonable to suppose it with Respect to any Part of the Creation, 'tis Especially so with Respect to reasonable intelligent Creatures; who are next to GOD in the Gradation of the different Orders of Beings, 
and whose Business is most immediately with GOD; who were made on Purpose for those Exercises that do respect God, and wherein they have nextly to do with God: for Reason teaches that Man was made to serve and glorify his Creator. And if it be rational to suppose that GOD immediately communicates himself to Man in any Affair, it is in this. 'Tis rational to suppose that GOD would reserve that Knowlege and Wisdom, that is of such a divine and excellent $\mathrm{Na}$ ture, to be bestowed immediately by himself, and that it should not be left in the Power of second Causes. Spiritual Wisdom and Grace is the highest and most excellent Gift that ever GOD bestows on any Creature: In this the highest Excellency and Perfection of a rational Creature consists. 'Tis also immensely the most important of all divine Gifts: 'Tis that wherein Mans Happiness consists, and on which his everlasting Welfare depends. How rational is it to suppose that GOD, however he has left meaner Goods and lower Gifts to second Causes, and in some sort in their Power, yet should reserve this most excellent, divine, and important of all divine Communications, in his own Hands, to be bestowed immediately by himself, as a thing too great for second Causes to be concern'd in? 'Tis rational to suppose that his Blessing should be immediately from GOD; for there is no Gift or Benefit that is in it self so nearly related to the divine Nature, there is nothing the Creature receives that is so much of GOD, of his Nature, so much a Participation of the Deity: 'Tis a Kind of Emanation of GOD's Beauty, and is related to GOD as the Light is to the Sun. 'Tis therefore congruous and fit, that when it is given of 
GOD, it should be nextly from himself, and by himself, according to his own Sovereign Will.

'TIS rational to suppose, that it should be beyond a Man's Power to obtain this Knowlege, and Light, by the meer Strength of natural Reason; for 'tis not a Thing that belongs to Reason, to see the Beauty and Loveliness of spiritual things; it is not a speculative thing, but depends on the Sense of the Heart. Reason indeed is necessary in order to it, as 'tis by Reason only that we are become the Subjects of the means of it; which means I have already shown to be necessary in order to it, though they have no proper causal Influence in the Affair. 'Tis by Reason, that we become possessed of a notion of those Doctrines that are the Subject Matter of this divine Light; and Reason may many ways be indirectly, and remotely an Advantage to it. And Reason has also to do in the Acts that are immediately consequent on this Discovery: A seeing the Truth of Religion from hence, is by Reason; though it be but by one step, and the Inference be immediate. So Reason has to do in that accepting of, and trusting in CHRIST, that is consequent of it. But if we take Reason strictly, not for the Faculty of mental Perception in general, but for Ratiocination, or a Power of Inferring by Arguments; I say if we take Reason thus, the perceiving of spiritual Beauty and Excellency no more belongs to Reason, than it belongs to the Sense of feeling to perceive Colours, or to the Power of seeing to perceive the Sweetness of Food. It is out of Reason's Province to perceive the Beauty or Loveliness of any 
thing: Such a Perception don't belong [28] to that Faculty. Reason's Work is to perceive Truth, and not Excellency. 'Tis not Ratiocination that gives Men the Perception of the Beauty and Amiableness of a Countenance; tho' it may be many ways indirectly an advantage to it; yet 'tis no more Reason that immediately perceives it, than it is Reason that perceives the Sweetness of Honey: It depends on the Sense of the Heart. Reason may determine that a Countenance is Beautiful to others, it may determine that Honey is sweet to others; but it will never give me a Perception of its Sweetness.

I will conclude with a very brief Improvement of what has been said.

First, THIS Doctrine may lead us to reflect on the Goodness of GOD, that has so ordered it, that a saving Evidence of the Truth of the Gospel is such, as is attainable by Persons of mean Capacities, and Advantages, as well as those that are of the greatest Parts and Learning. If the Evidence of the Gospel depended only on History, and such Reasonings as learned Men only are capable of, it would be above the Reach of far the greatest part of Mankind. But Persons, with but an ordinary Degree of Knowlege, are capable without a long and subtil Train of Reasoning, to see the divine Excellency of the things of Religion: They are capable of being taught by the Spirit of GOD, as well as learned Men. The Evidence that is this Way obtained, is vastly better and more satisfying, than all that can be obtain'd by the Arguings of those that are most Learned and great- 
est Masters of Reason. And Babes are as capable of knowing these things, as the wise and prudent; and they are often hid from these, when they are revealed to those. I Cor. I. 26, 27. For ye see your Calling Brethren, how that not many wise Men, after the Flesh, not many mighty, not many noble are called. But GOD hath chosen the foolish things of the World.-

Secondly. THIS Doctrine may well put us upon examining our selves, whether we have ever had his $d i$ vine Light, that has been described, let into our Souls. If there be such a thing indeed, and it ben't only a Notion, or Whimsy of Persons of weak and distempered Brains, then doubtless 'tis a thing of great Importance, whether we have thus been taught by the Spirit of GOD; whether the Light of the Glorious Gospel of CHRIST, who is the Image of GOD hath shined into us, giving us the Light of the Knowledge of the Glory of GOD, in the Face of $F E S U S$ CHRIST; whether we have seen the Son, and believed on him, or have that Faith of Gospel Doctrines that arises from a spiritual Sight of CHRIST.

Thirdly. ALL may hence be exhorted, earnestly to seek this spiritual Light. To influence and move to it, the following things may be consider'd.

I. THIS is the most excellent and divine Wisdom, that any Creature is capable of. 'Tis more excellent than any human Learning; 'Tis far more excellent, than all the Knowlege of the greatest Philosophers, or States-men. Yea the least Glimpse of the Glory of GOD in the Face of CHRIST doth more ex- 
alt and enable the Soul, than all the Knowlege of those that have the greatest speculative Understanding in Divinity, without Grace. This Knowlege has the most noble Object that is, or can be, viz the divine Glory, and Excellency of GOD, and CHRIST. The Knowlege of these Objects is that wherein consists the most excellent Knowlege of the Angels, yea, of GOD himself,

2. THIS Knowlege is that which is above all others Speet and Foyful. Men have a great deal of Pleasure in human Knowlege, in Studies of natural things; but this is nothing to that Joy which arises from this divine Light shining into the Soul. This Light gives a View of those things that are immensely the most exquisitely Beautiful, and capable of delighting the Eye of the Understanding. This spiritual Light is the dawning of the Light of Glory in the Heart. There is nothing so powerful as this to support Persons in Affliction, and to give the Mind Peace and Brightness, in this stormy and dark World.

3. THIS Light is such as effectually influences the Inclination, and changes the Nature of the Soul. It assimilates the Nature to the divine Nature, and changes the Soul into an Image of the same Glory that is beheld. 2 Cor. 3. 18. But we all open Face beholding as in a Glass the Glory of the Lord, are changed into the same Image, from Glory to Glory, even as by the Spirit of the Lord. This Knowlege will wean from the World, and raise the Inclination to heavenly things. It will turn the Heart to GOD as the Fountain of Good, and to choose him for the only Portion. This Light, and this only, 
will bring the Soul to a saving Close with CHRIST. It conforms the Heart to the Gospel, mortifies its Enmity and Opposition against the Scheme of Salvation therein revealed: It causes the Heart to embrace the joyful Tidings, and entirely to adhere to, and acquiesce in the Revelation of CHRIST as our Saviour: It causes the whole Soul to accord and Symphonize with it, admitting it with entire Credit and Respect, cleaving to it with full Inclination and Affection. And it effectually disposes the Soul to give up it self entirely to CHRIST.

4. THIS Light and this only has its Fruit in an universal Holiness of Life. No merely notional or speculative Understanding of the Doctrines of Religion, will ever bring to this. But this Light as it reaches the bottom of the Heart, and changes the Nature, so it will effectually dispose to an universal Obedience. It shews GOD's worthiness to be obeyed and served. It draws forth the Heart in a sincere Love to GOD, which is the only Principle of a true, gracious and universal Obedience. And it convinces of the Reality of those glorious Rewards that GOD has promised to them that obey him.

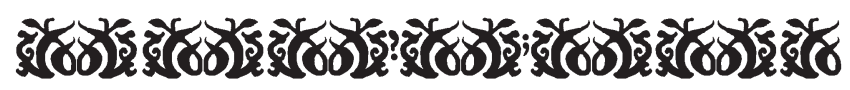

$$
F I N I S \text {. }
$$

\section{(ce)}




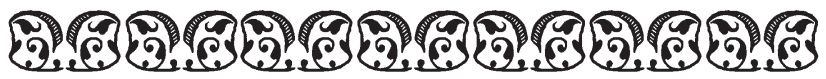

[Taken from the Excellent Dr. Watts's Hymns.]

The Humble enlightened, and Carnal Reason bumbled: Or, The Sovereignty of Grace, Luke 10. 21, 22.

$\mathrm{T}$ here was an Hour when CHRIST rejoyc'd, And spoke his Joy in Words of Praise;

Father, I thank thee, mighty God, Lord of the Earth and Heavens and Seas.

I thank thy Sov'reign Pow'r and Love, That crowns my Doctrine with Success; And makes the Babes in Knowlege learn The Heights, and Breadths, and Lengths of Grace.

But all this Glory lies conceal'd From Men of Prudence and of Wit : The Prince of Darkness blinds their Eyes, And their own Pride resists the Light.

Father, 'tis thus, because thy Will Chose and ordain'd it should be so ; 'Tis thy Delight t' abase the Proud, And lay the haughty Scorner low.

There's none can know the Father right, But those who learn it from the Son; Nor can the Son be well receiv'd, But where the Father makes him known.

Then let our Souls adore our God, That deals his Graces as he please;

Nor gives to Mortals an Account

Or of his Actions, or Decrees.

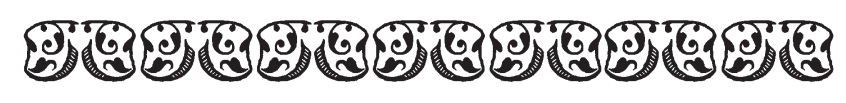




\title{
Afterword
}

\author{
by Reiner Smolinski
}

J

ONATHAN EdWARDS (1703-I758), colonial America's greatest thinker, theologian of the first order, and congregational clergyman, was born in Northampton, Massachusetts. Not quite 13, Jonathan Edwards entered Yale in 1716 , graduated four years later, and continued his study of theology until he received a call to a Presbyterian church in New York in 1722. Two years later, Edwards was appointed as tutor at Yale, but poor health forced him to resign from his position there. In 1726 , he returned to his place of birth to become an assistant to his grandfather Solomon Stoddard. Edwards married Sarah Pierpont in 1727 and after Stoddard's death in 1729 became teacher at his Northampton congregation.

Among Edwards' published works of the period is the tract God Glorified in the Work of Redemption by the Greatness of Man's Dependence ( $173 \mathrm{I}$ ). As if to rekindle the Preparationist debate of a century earlier, Edwards tried to undo what his maternal grandfather Solomon Stoddard had long established as a received practice in the Connecticut Valley: church membership based on "moral uprightness" rather than conversion process and test of faith. God Glorified stresses man's passivity in the process of regeneration, the certainty of which could only be measured in spiritual joy arising from the soul's overwhelming attraction to God's holiness and beauty. His sermons during the 1730 stressed the process of regeneration and struck a responsive cord among his parishioners, many of whom spontaneously assembled in prayer meetings. These early stirrings of the Great Awakening were intensified by Edwards' famous sermon $A$ Divine and Supernatural Light, Immediately Imparted to the Soul by the Spirit of God (I734). Through a fascinating process of canceling out his opponents' positions, Edwards clearly defines the workings of God's grace in the human soul. He distinguishes between "Common Grace" (intrinsic to virtually all unregenerate), which acts upon the mind of natural man and assists the faculties of the soul in their natural course; and "Special Grace" (intrinsic to true saints only), which acts in the human heart and unites with the mind of the saint as a new 
supernatural principle of life and action that restores human faculties to their proper place. God's spiritual light therefore does not consist of making impressions on the Imagination nor does it teach any new dogmas; it only gives a due apprehension of God's beauty. Hence a saint with indwelling grace does not merely believe rationally that God is glorious, but has a due sense of God's glory in his own heart. Whereas the head can merely sustain a speculative or notional knowledge of beauty, the heart delights in the idea of it, and the will prompted by the affections for the highest good embraces the virtuous act. In Edwards' illustration, the unregenerate can rationally attain a sense of God's beauty, but only the sanctified can attain full conviction and immediate evidence of God's grace: one can have a rational sense of the sweetness of honey, but the true sense of its taste can only be attained through experience. Edwards' distinction is echoed in what Samuel Taylor Coleridge would call primary and secondary beauty.

The surprising awakenings of 1730 s brought large numbers of new members to the communion table. Edwards describes the events in his Faithful Narrative of the Surprising Work of God (1737), which helped pave the way for George Whitefield's revival, the Great Awakening of $1740-1745$. In I 739 Edwards preached a long series of sermons on redemption, laying the foundation for his posthumous publication $A$ History of the Work of Redemption (Edinburgh, 1774). This millenarian work outlines God's providentialism in the history of the church from Old Testament times to the Second Coming. Edwards' preaching of the redemption cycle contributed to massive awakenings and so drew biting criticism from his Old Light colleagues. In his Distinguishing Marks of the Work of the Spirit of God (174I), Some Thoughts Concerning the Present Revival of Religion in New England (1743), and his Treatise Concerning Religious Affections ( 1746$)$, Edwards defends the Awakening against those who objected that these mass conversions were little more than enthusiasm-dangerous delusions of the senses-rather than a true outpouring of God's grace. Among Edwards' millenarian works is his Humble Attempt to Promote Visible Union of God's People in Extraordinary Prayer for the Revival of Religion (1747)-a concerted effort between Edwards and his Scottish colleagues William McCulloch and John Erskine to unite all Christians the world over to usher in the Second Coming.

If Edwards' fervent belief in the imminence of the millennium governed the writing of An Humble Attempt, his Treatise Concerning Religious Affections ( $\mathrm{r} 746$ ) tried to combat the inroads of Arminianism in New England. 
Several earlier defections from the orthodox cause, including that of 'Timothy Cutler, president of Yale, and of members of Edwards' own family, called for an all-out attack on Jacob Arminius. In many respects, Solomon Stoddard, had inadvertently contributed to the rise of Arminianism in Northampton. In further relaxing the Half-Way Covenant (I662), which admitted to the Lord's Supper the unconverted offspring of full members, Stoddard had seemingly flung open the church doors for anyone willing to abide by his minimalist principles of sincere moral conduct. Thus he had reduced the Lord's Supper to little more than a means of regeneration, where it had once stood as as a seal of God's covenant and symbol of His union with all true saints. Hence Edwards' Treatise Concerning Religious Affections (1746) and his later opus Freedom of the Will (1754) tried to undo his grandfather's liberal admissions policy by distinguished between the true and saving principles of religious affections, and mere enthusiasm or feelings of momentary elevation. His subsequent Account of the Life of the Late Reverend Mr. David Brainerd (1749) in a sense is an elucidation of these principles embedded in the exemplary history of a true saint.

Because of the divisiveness of the Great Awakening coupled with his return to admission tests, Edwards faced considerable resistance from a congregation long used to Stoddard's open-door policy. When the struggle for supremacy came to a climax, Edwards was summarily dismissed from his Northampton pulpit in $175^{\circ}$. His Farewell Sermon (1750) is a testimony to his convictions and a reprimand of his three principal opponents whose namesakes (Peter, John, and James) were similarly reproached by Christ for their spiritual sleep. Ousted from his pulpit, Edwards moved to the hamlet of Stockbridge (175I), an Indian mission in western Massachusetts. In 1757 , he was offered the presidency of Princeton, vacated by the sudden death of Aaron Burr, Edwards' son-in-law. Edwards assumed his duties at Princeton, in January of ${ }_{1758}$. Within three months, he died of a botched smallpox inoculation. His wife, Esther, met with a similar fate in October of the same year.

During his time in Stockbridge, Edwards wrote two of his greatest philosophical works against the spread of Arminianism, demonstrating the adaptability of Calvinism to the needs of a new age: Freedom of the Will (1754) and The Great Christian Doctrine of Original Sin Defended (1758). Both works employ Ramist logic in the context of Lockean faculty psychology to demonstrate that the faculty of human will is not totally free but con- 
ditioned by existing inclinations or circumstances. Prelapsarian Adam, according to Jonathan Edwards, was endowed with the two principles: SelfLove and Disinterested Benevolence. Together they maintained Adam's freedom to choose the highest Good. Yet when Adam deliberately resisted the divine injunction, God removed the principle of benevolence and so the balancing element in Adam's nature. Henceforth principally controlled by self-love, Adam's faculty of volition was governed by his fall from grace. Forever after, his memory, imagination, understanding, affection, and volition, were incapable of loving God unconditionally. Ruled by self-love, Adam's affections necessarily inclined toward inferior ends, and his will and actions were thus determined by his inability to choose absolute Good. Through imputation of Adam's sin in his offspring, choice and culpability were thus conditioned by human inclination toward selfish ends. In singling out the Episcopalian John Taylor, Edwards argued that his Arminian colleague failed to realize that man's a priori condition inevitable limited his choices to the parameters of his fallen nature. Free will was therefore an illusion. Edwards' posthumous work Nature of True Virtue (1765) can be seen as an amplification of his Divine and Supernatural Light (r734) and as his final word on Arminianism. True love of God and union with the deity can only be achieved through grace.

The work reprinted above (courtesy of the American Antiquarian Society) is a representative example of Edwards' incisive logic employed in the work of salvation. A Divine and Supernatural Light, Immediately Imparted to the Soul by the Spirit of God (1734) defines the work of grace in the process of regeneration.

\section{头系}

The text of this edition is based upon the first edition, printed in Boston in 1734 by Kneeland and Green. Emendations made to the text for this edition include the following:

Page 3 , line 4: which in which is in 


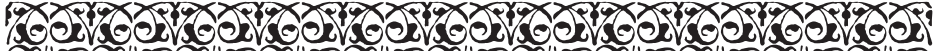

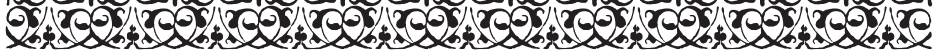

Set in IM Fell English, a typeface originally cut by

Christoffel van Dijck and Robert Granjon in the late seventeenth century, and digitized and furnished by Igino Marini

http://woww.iginomarini.com/fell.html

Page design and ornamentation

adapted from the Boston

first edition of $\mathrm{I} 734$.

Composition by

Paul Royster.

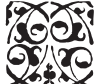

The Fell Types 